SPECIAL VOLUME

\title{
Geochemistry and geodynamic setting of Paleoproterozoic granites of Lesser Garhwal Himalaya, India
}

\author{
Sumit Mishra ${ }^{1}$, Vinod K. Singh ${ }^{2}$, Alexander I. Slabunov ${ }^{3}$, H.C. Nainwal ${ }^{1}$, Pradip K. \\ Singh $^{4}$, Neeraj Chaudhary ${ }^{2}$, D.C. Nainwal ${ }^{5}$ \\ ${ }^{1}$ Department of Geology, Hemvati Nandan Bahuguna Garhwal University, Srinagar Garhwal, Uttarakhand (sumit.geo@hnbgu.ac.in) \\ ${ }^{2}$ Department of Geology, Institute of Earth Science, Bundelkhand University, Jhansi, Uttar Pradesh, India \\ ${ }^{3}$ Institute of Geology, Karelian Research Centre, RAS, Petrozavodsk, Russia \\ ${ }^{4}$ División de Geociencias Aplicadas, Instituto Potosino de Investigación Científica y Tecnológica (IPICYT), Camino a la Presa, San José 2055, San \\ Luis Potosí 78216, Mexico \\ ${ }^{5}$ Govt. Degree College, Gaza (Pokhari-Quili), Tehri-Garhwal, Uttarakhand
}

\author{
* Corresponding author : ineerajchaudhary@gmail.com \\ Tel.: +91-7579160441 \\ Received: Sept 19, 2018; Accepted: Feb 22, 2019. \\ DOI: 10.25299/jgeet.2019.4.2-2.2138
}

\section{Abstract}

The granite and gneisses rocks are well exposed around Toneta, Tilwara and Chirbatiyakhal region in the Lesser Garhwal Himalaya have less studied which consider as Paleoproterozoic age. The granites from Toneta area are classified as K-rich peraluminous granite with low $\mathrm{Na}_{2} \mathrm{O}$ varies from 0.74 to $2.4 \mathrm{wt} . \%$ and high $\mathrm{K}_{2} \mathrm{O}$ content varies from 5.0 to 6.91 wt.\% The average $\mathrm{Al}_{2} \mathrm{O}_{3}$ (12.7 wt.\% in the granite is greater than the total alkalies $\left(\mathrm{Na}_{2} \mathrm{O}+\mathrm{K}_{2} \mathrm{O}=\mathrm{Av} .7 .62 \mathrm{wt} . \%\right.$, the $\mathrm{TiO}_{2}$ content is low ranging from 0.1 to 0.28 wt. \% In the $\mathrm{Y}+\mathrm{Nb}-\mathrm{Rb}, \mathrm{Y}-\mathrm{Nb}, \mathrm{Ta}+\mathrm{Yb}-\mathrm{Rb}$, and $\mathrm{Yb}-\mathrm{Ta}$ discrimination diagram of Pearce et al. (1984) show that the Toneta granites mostly plots within the syn-collision granite fields. This is typical collisional granite.

Keywords: Paleoproterozoic granite, Garhwal Himalaya, syn-collision granite, geodynamic setting, Lesser Himalaya

\section{Introduction}

To Granites have provided a constant focus for controversy among geologists on account of their inherent diversity and their association with very wide spectrum of geological phenomenon since the beginning of geology in the modern sense which can be arbitrarily judged to date from 1838 with the publication of Lyell's "Principles of Geology" (in Islam et al., 2005).

The Himalayan mountain belt has evolved due to the collision of the Eurasian and Indian Plates and extends along an arc having a convexity towards south (Patriat and Achache, 1984). It measures for about $2400 \mathrm{~km}$ in length with a width of about $320 \mathrm{~km}$. The Himalaya is broadly classified as i) Sub-Himalaya, ii) Lesser Himalaya, iii) Higher Himalaya, iv) Tethys Himalaya, and v) Trans Himalaya (Fig. 1a). Lesser Himalayan sequence is separated from the Higher Himalayan crystalline by a deep seated tectonic lineament called Main Central Thrust (MCT; Heim and Gansser, 1939). Fuchs and Sinha (1978), Sinha (1989), Thakur (1992), Gansser (1993) and Saklani (1993) suggest that the MCT is not a single thrust in the Garhwal region, but composed of three tectonic planes i.e. MCT-I, -II and -III developed by the duplex mechanism of thrust tectonics (Fig. 1b; Saklani et al., 1991). The extensive work of Valdiya (1980) from Kumaon Himalaya show that several Paleoproterozoic granites bodies occur in Lesser Himalayan sequence and it found all along the $2000 \mathrm{~km}$ Himalayan belt starting from Besham in Swat valley (NW Himalaya) to the Bomdila gneiss in the NE Himalaya (Islam et al., 2005; Phukon et al., 2018 and references therein). The granites occurring in the Himalaya are classified in to four groups (Islam et al., 2005): i) Proterozoic granites (2200 - 1800 Ma; 1400 - 1200 Ma; from Lesser and Higher Himalaya), ii) Early Paleozoic granites (600 - $500 \mathrm{Ma}$ ), iii) intrusive phases of Ladakh plutonic complex (102 $\pm 3 \mathrm{Ma}$ and $42-30 \mathrm{Ma}$ ), and iv) Tertiary leucogranites (30 - $12 \mathrm{Ma}$ ).

Granitic gneisses and granitic augen gneisses exposed in the Lesser Himalayan zone have extended as Proterozoic ages (2200 - $1800 \mathrm{Ma}$; Table 1). These rocks from Lesser and Higher Himalaya are considering as part of the peninsular India, and the occurrences of granites from Lesser Himalayan sequence are well exposed in Himachal and Garhwal - Kumaon regions (Saklani et al., 1991; Saklani, 1993; Singh et al., 1998). The Outer Himalaya and Indo-Gangetic plain formed, after eroded material from Higher Himalaya during Himalayan orogeny, towards south of Lesser Himalaya. 


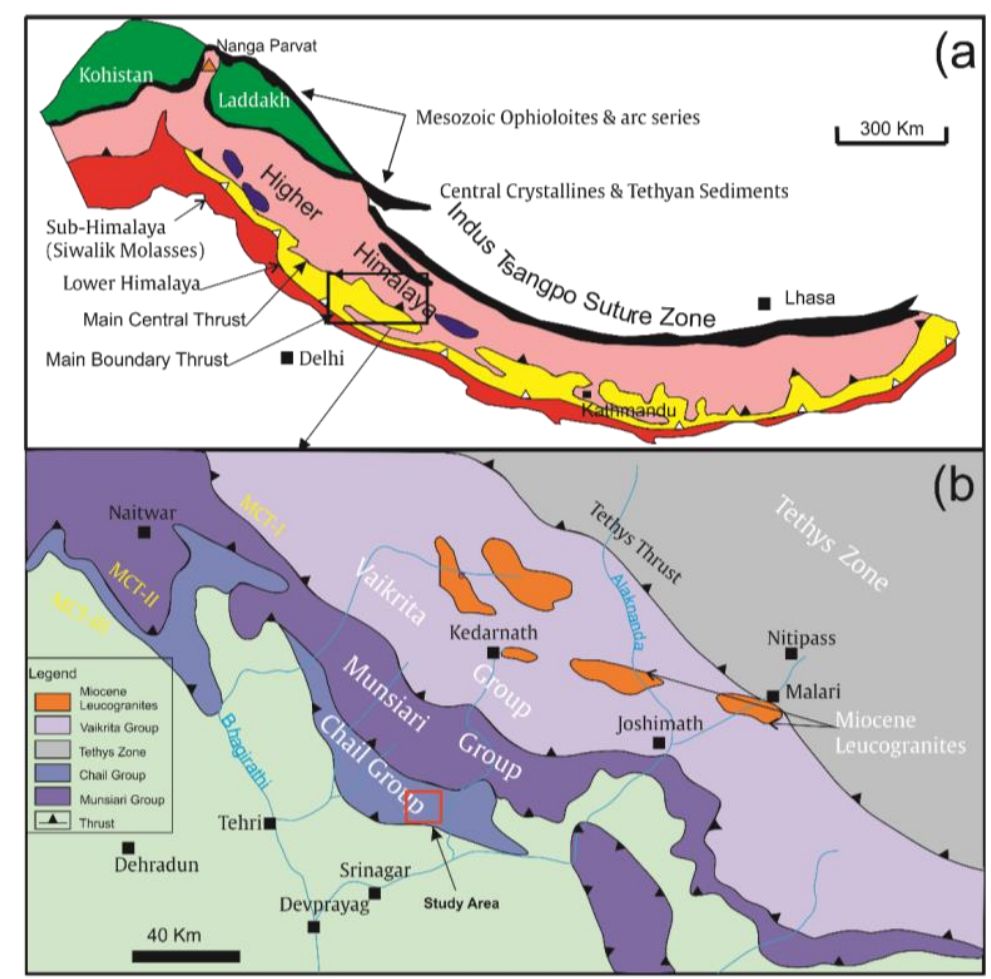

Fig. 1. (a) General tectonic map of Himalaya after Gansser (1964), and (b) General tectonic map of Garhwal Himalaya after Valdiya (1980).

Table 1. Summarized geochronological ages of Himalayan Proterozoic granites (after Islam et al., 2005; Singh et al., 2009).

\begin{tabular}{lll}
\hline Locality & Age & References \\
\hline Jeori-Wangtu & $1860 \mathrm{Ma}$ & Miller et al., (2000) \\
Wangtu, Sutlej & 2025 to $2075 \mathrm{Ma}$ & Kwatra et al., (1986) \\
Wangtu & $1895 \pm 64 \mathrm{Ma}$ & Rao et al., (1995) \\
Wangtu & $1866 \pm 10 \mathrm{Ma}$ (U-Pb Zr) & Singh et al., (1994) \\
Magladgad & $2068 \pm 5 \mathrm{Ma}$ (U-Pb Zr) & \\
Bandal & $1840 \pm 0.0027 \mathrm{Ma}$ & Frank et al., (1977) \\
Nirath-Baragaon & $1430 \pm 150 \mathrm{Ma}$ & Bhanot et al., (1978) \\
Bandal & $1220 \pm 100 \mathrm{Ma}$ & Bhanot et al., (1979) \\
Dhakuri & $2315 \pm 135 \mathrm{Ma}$ & Pandey et al., (1981) \\
Chailli, Bhilangna valley & $2121 \pm 60 \mathrm{Ma}$ & Raju et al., (1982) \\
Rihee-Gangi, Bhilangna valley & $1841 \pm 86 \mathrm{Ma}$ & Singh et al., (1986) \\
Ghuttu, Bhilangna valley & $1763 \pm 116 \mathrm{Ma}$ & Singh et al., (1985) \\
Chirpatiyakhal, Bhilangna valley & $1708 \pm 131 \mathrm{Ma}$ & \\
Amritpur & $1585 \pm 192 \mathrm{Ma}$ & \\
Joshimath-Guptakashi & $1950 \pm 200 \mathrm{Ma}$ & Pandey et al., (1981) \\
Naitwar, Tons valley & $1811 \pm 133 \mathrm{Ma}$ & Singh et al., (1986) \\
Hanumanchatti, Yamuna valley & $1972 \pm 102 \mathrm{Ma}$ & \\
Bhatwari, Bhagirathi valley & $2047 \pm 119 \mathrm{Ma}$ & \\
Munsiari & 1830 to $1890 \mathrm{Ma}$ & Bhanot et al., (1977) \\
Rameshwar granite & $1820 \pm 130 \mathrm{Ma}$ & Trivedi et al., (1984) \\
Chiplakot Crystalline Belt (granite gneiss) & $1920.7 \pm 4.2 \mathrm{Ma}$ & Phukon et al., (2018) \\
Namik & $1910+88 \mathrm{Ma}$ & Singh et al., (1985) \\
Tawaghat & $1906+220 \mathrm{Ma}$ & Powell et al., (1979) \\
Almora-Askot & $1620 \pm 90 \mathrm{Ma}$ & Pandey et al., (1981) \\
Askot Dharamgarh & $1795 \pm 30 \mathrm{Ma}$ & Trivedi et al., (1984) \\
Ramgarh granite & $1765 \pm 60 \mathrm{Ma}$ & Pandey et al., (1981) \\
Gwaldam granite & $1300 \pm 80 \mathrm{Ma}$ & Trivedi et al., (1984) \\
Lingtse granite, NE Himalaya & $1700 \pm 70 \mathrm{Ma}$ & Paul et al., (1996) \\
Darjeling-Sikkim, granite gneiss & $1678 \mathrm{Ma} \mathrm{(Rb-Sr} \mathrm{whole} \mathrm{rock)}$ & \\
Bomdila gneiss & $1792 \mathrm{Ma}(\mathrm{Pb}-\mathrm{Pb}$ age) & Rao, (1998) \\
& $1874 \pm 24 \mathrm{Ma}(\mathrm{U}-\mathrm{Pb}$ Zr) & \\
\hline & $1827 \pm 95 \mathrm{Ma}(\mathrm{U}-\mathrm{Pb}$ Zr) & \\
\hline & & \\
& &
\end{tabular}


The Lesser Himal ayan zone comprises Paleoproterozoic granite, Paleozoic sedimentaries (e.g. slates, phyllites, quartzites) with pene-contemporaneous mafic volcanic (1.83 - $1.88 \mathrm{Ga}$ Sm-Nd T-CHUR modal ages; Miller et al., 2000). There is a period of felsic volcanism and granite emplacement occurred around $1.86-1.84 \mathrm{Ga}$ in NW Himalaya. Nd model ages for these granitic rocks extend to $2.63 \mathrm{Ga}$, indicating recycling of Archean continental crust (Miller et al., 2000). Still more studies are required especially from Garhwal Himalaya where limited data are available to set up Proterozoic magmatism. Therefore, Palaeoproterozoic granites are selected from Toneta area, Tilwara section for whole rock geochemical analysis to establish tectonic environment and geodynamic setting.

\section{Geology of the area}

It is supposed that the Indian crust was imbricated and different parautochthonous of deeper rocks from various tectonics levels by the duplex mechanism and thrusted on metasedimentary rocks of the Lesser Himalayan sequence. The study area is constituted by granite, quartzite, schist, gneisses and metabasics (Fig. 2). The undeformed granite exposed around Toneta area is considered as Bhatwari (= Chail/ Ramgarh) group (Valdiya 1980; Saklani et al., 1991). This rock unit has sheared up to 500 meters having brittle ductile deformation (mainly Indian plates basement rocks medium to high metamorphic grade) consider as characteristics of MCT-III zone in the Lesser Himalayan sequence. The rocks of Chail group are tectonically separated by Chail thrust (MCT-III) with massive white quartzite of the Garhwal group towards south (Valdiya, 1980; Saklani et al., 1991; Singh et al., 1998).

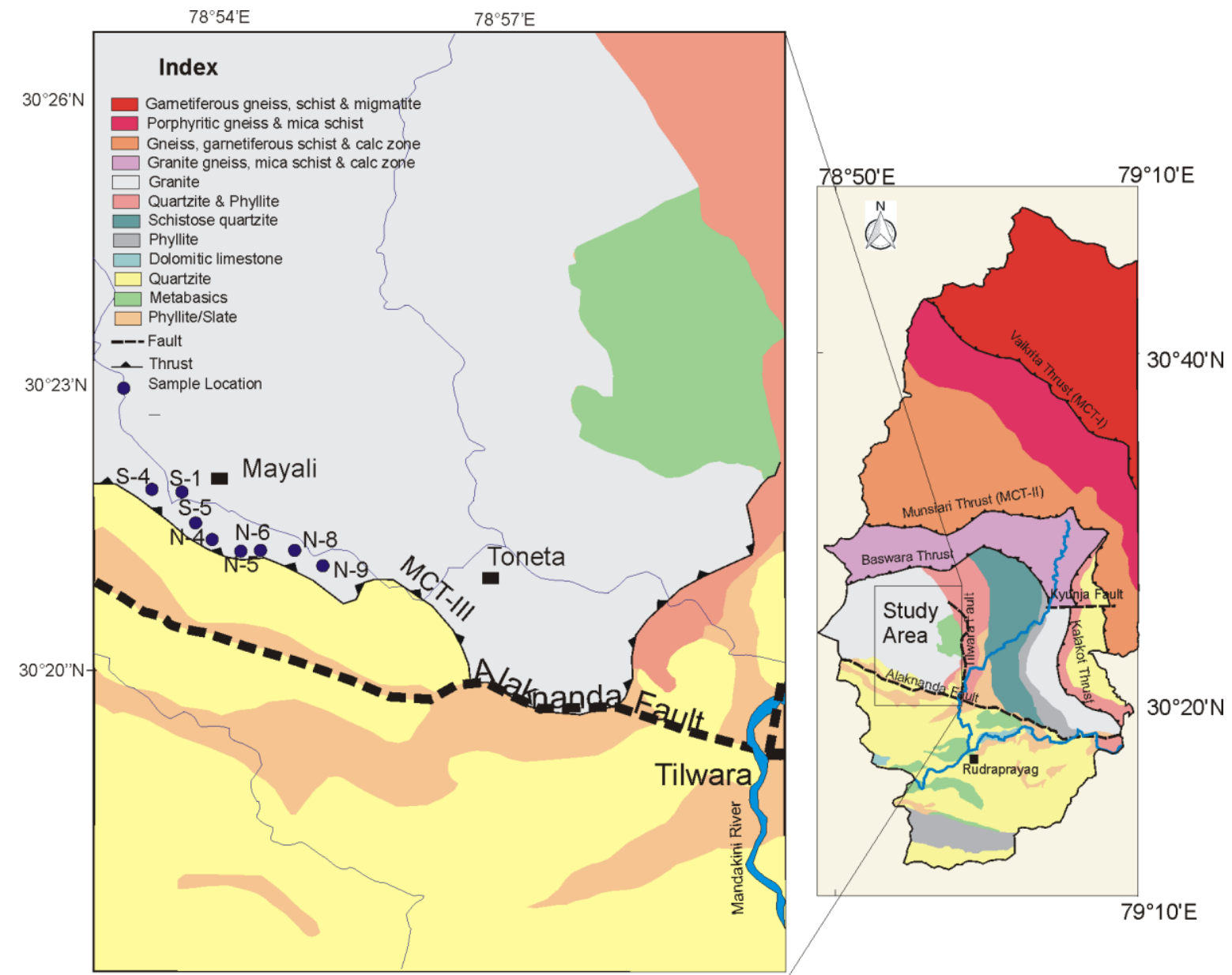

Fig. 2. Geological map of the area around Toneta, Rudraprayag, Lesser Garhwal Himalaya (after Valdiya, 1980). Analysed granite samples are given in Table 2.

The Toneta granites extend from $1.5 \mathrm{~km}$ west of Tilwara to Chirbatiyakhal in the east. They are well exposed around Toneta village and hence the name (Negi et al., 1980). These granitic rocks sometime associated with tourmaline granite, gneiss and quartz - sericite - schist (Fig. 3a). Tourmaline granite is medium to coarse grained with feldspar and quartz having subordinate tourmaline and biotite. The sample N-4, N-5 and N-6 are medium to coarse grained containing feldspar (microcline and plagioclase) and quartz, and accessory minerals are biotite and tourmaline. It is typical for MPG (Muscovite-bearing Peraluminous Granitoids) which common for collisional setting (Barbarin, 1999). Striation in tourmaline grains is seen near Toneta, where the grains are $0.5 \mathrm{~cm} \times 0.3 \mathrm{~cm}$ 
(avg.) in dimensions. Near Jakhal village and about $1 \mathrm{~km}$ west of Toneta, regular black band of tourmaline are seen in the granites, with a thickness of $0.5 \mathrm{~cm}$ to $1 \mathrm{~cm}$ and rock exposures occurring around 3 to $7 \mathrm{~m}$ bands. There is also sericitization of feldspar. At places the granite has become vary coarse grained, non- foliated porphyritic and rich in biotite (Fig. 3b). N-5 sample is fresh and fine grained rocks occur in very small area about $3 \mathrm{~km}$ west of Toneta village, exist in a road cutting section and have undeformed (Fig. 3b). The sample N-5 contains quartz and feldspar and subordinate mica minerals with fine grains. The other granite samples are also fresh which have developed crude foliation and schistosity (Fig. 3c).

The granite- gneiss (sample No. S-1, S-4 and S-5) are exposed around Mayali having quartz and flaky minerals. About $1 \mathrm{~km}$ south east of Mayali, augen gneisses are observed and some boudinage of quartzites are exposed in the granite gneiss. Similar structures are also reported by Negi et al. (1980) along the Helang gad fault and the rocks are highly scattered. The fine to medium grained quartz-talc-schist is reported by Negi et al. (1980) from Toneta to Mayali traverse which extending further towards North and have elongated quartz grains. Quartz - sericite schist is well developed in sheared zones, particularly along the Alaknanda thrust and in the upper Lastar gad valley and correlated with MCT-III of Saklani et al. (1991) which show thrusted contact with quartzite at southern side. These granites have well developed joint system and also traversed by epidiorites.

\section{Sampling and analytical techniques}

Based on criteria least alteration, seven representative samples of granite were analysed. The chemical composition of the rocks was determined at the Testing and Matter Analysis Centre, Institute of Geology, KarRC, RAS, Petrozavodsk, Russia. The detail methodology and precision is described by Svetov et al. (2015), Singh and Slabunov (2015), which profusely discussed in Slabunov and Singh (2018). To estimate rock-forming element concentrations, sample powder was first melted with sodium carbonate, and the resultant melt was then leached with diluted hydrochloric acid. $\mathrm{SiO}_{2}$ was first precipitated with gelatin from the resultant solution, and its percentage was estimated by the gravimetric method. Al, Fe, $\mathrm{Ca}$ and $\mathrm{Mg}$ concentrations in the solution were then calculated complexometrically and $\mathrm{Ti}$ and $\mathrm{P}$ concentrations photometrically. Calculation accuracy was determined from acceptable discrepancy between the results of two parallel estimations which does not exceed $0.7 \%$ for $\mathrm{Si}, 0.5 \%$ for $\mathrm{Al}$, Fe, $\mathrm{Ca}$ and $\mathrm{Mg}$ and $0.3 \%$ for $\mathrm{Ti}$ and $\mathrm{P}$.

The concentrations of minor elements in the samples were estimated by the inductively coupled plasma mass spectrometry (ICP-MS) method on an X Series-2 ICP-MS (Thermo Scientific, USA). The samples were decomposed by acid dissolution in an open system. Weighted portions of samples with a mass of $0.1 \mathrm{~g}$ were used for analysis. The samples analyzed were decomposed together with reference samples (blank samples) and one standard sample. The major elements and their calculated CIPW weight norms and also trace elements data are given in Table 2 and Table 3.

Table 2. Major oxides (wt.\% Elemental data and CIPW Weight Norms for the analyzed sample of granites, Tilwara, Lesser Garhwal Himalaya (sample locations are marked in Fig. 2).

\begin{tabular}{llllllll}
\hline Sample Name & $\mathrm{S}-1$ & $\mathrm{~S}-4$ & $\mathrm{~S}-5$ & $\mathrm{~N}-4$ & $\mathrm{~N}-6$ & $\mathrm{~N}-5$ & $\mathrm{~N}-9$ \\
\hline Lat. (N) & $30^{\circ} 22^{\prime} 35^{\prime \prime}$ & $30^{\circ} 22^{\prime} 33^{\prime \prime}$ & $30^{\circ} 22^{\prime} 14^{\prime \prime}$ & $30^{\circ} 22^{\prime} 11^{\prime \prime}$ & $30^{\circ} 21^{\prime} 59^{\prime \prime}$ & $30^{\circ} 21^{\prime} 57^{\prime \prime}$ & $30^{\circ} 21^{\prime} 42^{\prime \prime}$ \\
Long. (E) & $78^{\circ} 53^{\prime} 47^{\prime \prime}$ & $78^{\circ} 53^{\prime} 22^{\prime \prime}$ & $78^{\circ} 53^{\prime} 44^{\prime \prime}$ & $78^{\circ} 53^{\prime} 53^{\prime \prime}$ & $78^{\circ} 54^{\prime} 15^{\prime \prime}$ & $78^{\circ} 54^{\prime} 10^{\prime \prime}$ & $78^{\circ} 54^{\prime} 45^{\prime \prime}$ \\
$\mathrm{SiO}_{2}$ & 73.05 & 76.62 & 74.8 & 76.68 & 74.66 & 71.84 & 95.06 \\
$\mathrm{TiO}_{2}$ & 0.2 & 0.1 & 0.22 & 0.18 & 0.25 & 0.28 & 0.11 \\
$\mathrm{Al}_{2} \mathrm{O}_{3}$ & 13.5 & 12.24 & 12.43 & 11.67 & 12.67 & 13.7 & 1.64 \\
$\mathrm{Fe}_{2} \mathrm{O}_{3}$ & 0.16 & 0.69 & 0.054 & 0.46 & 0.66 & 0.63 & 0.33 \\
$\mathrm{FeO}$ & 1.14 & 0.86 & 1.43 & 1.44 & 1.44 & 1.94 & 0.72 \\
$\mathrm{MnO}$ & 0.012 & 0.014 & 0.018 & 0.013 & 0.024 & 0.024 & 0.013 \\
$\mathrm{MgO}$ & 1.86 & 0.46 & 0.62 & 1.13 & 0.76 & 0.82 & 0.51 \\
$\mathrm{CaO}$ & 1.01 & 0.29 & 1.44 & 0.36 & 0.29 & 0.36 & 0.36 \\
$\mathrm{Na} \mathrm{O}_{2} \mathrm{O}$ & 0.85 & 2.27 & 2.38 & 1.27 & 0.74 & 2.4 & 0.04 \\
$\mathrm{~K} 2 \mathrm{O}$ & 6.63 & 5.3 & 5.55 & 5.0 & 6.91 & 6.42 & 0.31 \\
$\mathrm{P} \mathrm{O}_{5}$ & 0.22 & 0.15 & 0.2 & 0.16 & 0.16 & 0.12 & 0.31 \\
$\mathrm{H}_{2} \mathrm{O}$ & 0.03 & 0.17 & 0.03 & 0.1 & 0.07 & 0.17 & 0.08 \\
$\mathrm{ClPW}$ Weight & $\mathrm{Nom}$ & & & & & & \\
$\mathrm{Q}$ & 37.67 & 41.86 & 35.25 & 47.26 & 41.83 & 30.47 & 92.49 \\
$\mathrm{C}$ & 3.62 & 2.60 & 0.37 & 3.90 & 3.83 & 2.44 & 1.24 \\
$\mathrm{Or}$ & 39.18 & 31.32 & 32.80 & 29.55 & 40.84 & 37.94 & 1.83 \\
$\mathrm{Ab}$ & 7.19 & 19.21 & 20.14 & 10.75 & 6.26 & 20.31 & 0.34 \\
$\mathrm{An}$ & 3.57 & 0.46 & 5.84 & 0.74 & 0.39 & 1.00 & 0 \\
$\mathrm{Hy}$ & 6.29 & 2.02 & 3.80 & 4.81 & 3.63 & 4.67 & 2.16 \\
$\mathrm{Mt}$ & 0.23 & 1.00 & 0.08 & 0.67 & 0.96 & 0.92 & 0.48 \\
$\mathrm{II}$ & 0.38 & 0.19 & 0.42 & 0.34 & 0.48 & 0.53 & 0.21 \\
$\mathrm{Ap}$ & 0.521 & 0.36 & 0.48 & 0.38 & 0.38 & 0.29 & 0.65 \\
\hline $\mathrm{Sum}$ & 98.65 & 99.01 & 99.16 & 98.38 & 98.58 & 98.55 & 99.39 \\
\hline & & & & & & &
\end{tabular}




\section{Geochemistry and tectonic settings}

The K-rich granites from Toneta area are mostly calc-alkaline in nature classified as granite (Fig. 4a). The normative feldspar classification diagrams [Albite (Ab)-Orthoclase (Or)-Anorthite (An), O'Connor, 1965 and Barker, 1979] indicate that the Toneta granite falls in granite field (Fig. 4b). In granitoids $\mathrm{Na}_{2} \mathrm{O}$ is low and varies from 0.74 to 2.4 wt.\%and $\mathrm{K}_{2} \mathrm{O}$ content varies from 5.0 to 6.91 wt.\% $\mathrm{The} \mathrm{Al}_{2} \mathrm{O}_{3}$ content varies from 11.67 to 13.7 wt.\%except sample N-9 (95\%silica). The rocks are highly rich in $\mathrm{SiO}_{2}$ having range from 71.84 to 76.68 wt.\% Alumina content $\left(\mathrm{Al}_{2} \mathrm{O}_{3}: \mathrm{Av} .12 .7\right.$ wt.\%in the granitoids is greater than the total alkalies $\left(\mathrm{Na}_{2} \mathrm{O}+\mathrm{K}_{2} \mathrm{O}: \mathrm{Av} 7.62 \mathrm{wt}\right.$. $\%$, the $\mathrm{TiO}_{2}$ content in the granitoids are low ranging from 0.1 to $0.28 \mathrm{wt} . \%$ CIPW norms calculations, all the samples show normative corundum values ranging from 0.37 to 3.89 which is a typical in all granite samples of the Lesser Garhwal Himalaya with high normative Orthoclase and less normative Albite-Anorthite feldspar minerals (Table 2). The granites belong to high-K calc alkaline and shoshonite series (Fig. 5a), with mostly peraluminous in nature (Fig. 5b).

Table 3. Trace elements (in ppm) analytical data of the granites, Tilwara, Lesser Garhwal Himalaya.

\begin{tabular}{|c|c|c|c|c|c|c|c|}
\hline Sample Name & S-1 & S-4 & S-5 & $\mathrm{N}-4$ & $\mathrm{~N}-6$ & $\mathrm{~N}-5$ & $\mathrm{~N}-9$ \\
\hline $\mathrm{Cr}$ & 20.2 & 23.01 & 18.83 & 40.12 & 23.09 & 25.92 & 43.66 \\
\hline $\mathrm{Ni}$ & 12.03 & 9.53 & 10.15 & 8.34 & 13.24 & 15.28 & 20.91 \\
\hline Co & 1.78 & 1.13 & 1.73 & 1.65 & 2.24 & 4.88 & 2.19 \\
\hline Sc & 5.05 & 6.23 & 6.22 & 6.69 & 6.85 & 7.78 & 4.70 \\
\hline V & 26.03 & 49.46 & 44.97 & 47.01 & 25.59 & 109.80 & 57.32 \\
\hline $\mathrm{Cu}$ & 5.13 & 4.83 & 8.18 & 7.51 & 18.74 & 10.56 & 5.49 \\
\hline $\mathrm{Pb}$ & 11.84 & 19.72 & 39.24 & 16.47 & 32.29 & 22.40 & 3.37 \\
\hline $\mathrm{Zn}$ & 21.82 & 24.13 & 39.95 & 29.65 & 87.93 & 44.35 & 9.23 \\
\hline $\mathrm{Bi}$ & 1.59 & 0.93 & 0.57 & 1.88 & 37.93 & 0.25 & 0.19 \\
\hline $\mathrm{Cd}$ & 0.09 & 0.07 & 0.14 & 0.14 & 0.14 & 0.08 & 0.06 \\
\hline Sn & 23.79 & 27.83 & 13.06 & 11.76 & 14.51 & 9.51 & 5.28 \\
\hline W & 3.75 & 5.26 & 6.36 & 3.97 & 4.76 & 3.90 & 5.02 \\
\hline Mo & 0.36 & 0.46 & 0.31 & 0.44 & 0.46 & 0.59 & 0.91 \\
\hline $\mathrm{Sb}$ & 0.27 & 0.27 & 0.23 & 0.41 & 0.32 & 0.24 & 0.27 \\
\hline $\mathrm{Rb}$ & 386.7 & 434.8 & 374.8 & 301.5 & 438. & 333.1 & 21.2 \\
\hline CS & 13.52 & 17.97 & 12.44 & 16.99 & 15.56 & 12.52 & 0.88 \\
\hline $\mathrm{Ba}$ & 161.1 & 64.18 & 179.8 & 155. & 275.40 & 491.6 & 34.4 \\
\hline $\mathrm{Sr}$ & 15.11 & 15.30 & 40.68 & 16.31 & 18.31 & 45.68 & 10.57 \\
\hline $\mathrm{Tl}$ & 1.94 & 2.06 & 1.94 & 1.38 & 2.54 & 1.84 & 0.14 \\
\hline Ga & 18.28 & 17.90 & 17.23 & 17.14 & 18.06 & 19.43 & 3.31 \\
\hline $\mathrm{Li}$ & 13.44 & 8.71 & 9.02 & 18.23 & 13.13 & 14.07 & 3.82 \\
\hline $\mathrm{Ta}$ & 1.66 & 2.28 & 1.56 & 1.95 & 1.61 & 0.95 & 0.48 \\
\hline $\mathrm{Nb}$ & 10.77 & 10.69 & 11.27 & 12.60 & 12.28 & 11.03 & 4.93 \\
\hline $\mathrm{Hf}$ & 2.73 & 2.32 & 2.70 & 3.52 & 4.70 & $\varangle P O$ & 1.91 \\
\hline $\mathrm{Zr}$ & 63.08 & 50.20 & 70.74 & 93.74 & 117.10 & 1.89 & 57.89 \\
\hline$Y$ & 25.38 & 27.23 & 23.70 & 26.93 & 41.93 & 16.21 & 5.75 \\
\hline Th & 25.74 & 23.93 & 20.55 & 25.03 & 25.66 & 50.98 & 19.50 \\
\hline U & 9.88 & 12.97 & 3.52 & 6.83 & 9.27 & 3.28 & 6.22 \\
\hline La & 29.85 & 14.59 & 22.10 & 28.79 & 31.37 & 66.33 & 19.22 \\
\hline $\mathrm{Ce}$ & 61.83 & 33.25 & 44.93 & 59.19 & 62.66 & 137.60 & 37.84 \\
\hline $\mathrm{Pr}$ & 7.21 & 3.59 & 5.38 & 7.07 & 7.44 & 15.67 & 4.28 \\
\hline $\mathrm{Nd}$ & 24.75 & 12.47 & 18.61 & 24.16 & 26.14 & 53.84 & 14.18 \\
\hline $\mathrm{Sm}$ & 4.23 & 2.90 & 2.88 & 3.55 & 3.67 & 7.16 & 2.70 \\
\hline $\mathrm{Eu}$ & 0.37 & 0.19 & 0.47 & 0.42 & 0.51 & 0.83 & 0.39 \\
\hline $\mathrm{Gd}$ & 5.76 & 3.74 & 4.51 & 5.50 & 6.24 & 7.17 & 2.38 \\
\hline $\mathrm{Tb}$ & 1.00 & 0.79 & 0.80 & 0.94 & 1.15 & 0.96 & 0.32 \\
\hline Dy & 5.20 & 4.99 & 4.49 & 5.13 & 7.24 & 4.03 & 1.44 \\
\hline $\mathrm{Ho}$ & 0.91 & 0.96 & 0.85 & 0.96 & 1.42 & 0.66 & 0.23 \\
\hline $\mathrm{Er}$ & 2.01 & 2.44 & 2.06 & 2.27 & 3.77 & 1.34 & 0.58 \\
\hline $\mathrm{Tm}$ & 0.26 & 0.34 & 0.29 & 0.32 & 0.53 & 0.13 & 0.08 \\
\hline $\mathrm{Yb}$ & 1.37 & 2.00 & 1.62 & 1.61 & 3.16 & 0.66 & 0.49 \\
\hline Lu & 0.18 & 0.26 & 0.21 & 0.23 & 0.42 & 0.07 & 0.07 \\
\hline $\mathrm{Be}$ & 2.85 & 2.08 & 3.71 & 2.26 & 2.23 & 1.95 & 1.72 \\
\hline
\end{tabular}

Chondrite-normalized rare earth-element patterns (McDonough \& Sun 1995) of the granitoids show pronounced negative Eu anomaly ( $\mathrm{Eu} / \mathrm{Eu}^{*}=0.18$ to 0.36 , Fig. $6 \mathrm{a}$ ), pronounced enrichment in LREE and highly fractionation of heavy rare earth elements (HREE; LaN/LuN $=(5.81$ to 101.34). These rocks are also rich in LLE: $\mathrm{Cs}, \mathrm{Rb}, \mathrm{Th}, \mathrm{U}$, and $\mathrm{Pb}$ (see primitive mantle normalized, McDonough \& Sun 1995, Fig. 6b) and display negative $\mathrm{Nb}-\mathrm{Ti}$ anomalies (Fig. 6b). 
In the $\mathrm{Yb}+\mathrm{Ta}$ versus $\mathrm{Rb}$ and $\mathrm{Nb}$ versus $\mathrm{Y}$ discrimination diagram of Pearce et al. (1984), the Toneta granites mostly plots within the syn-collision granite fields (Fig. 7). The $R_{1}-R_{2}\left[R_{1}=4 S^{4+}-11\left(\mathrm{Na}^{+}+\mathrm{K}^{+}\right) 2\left(\mathrm{Fe}^{3+}+\mathrm{Ti}^{4+}\right.\right.$ ), molar; $\mathrm{R}_{2}$ $=6 \mathrm{Ca}^{2+}+2 \mathrm{Mg}^{2+}+\mathrm{Al}^{3+}$, molar] tectonic discrimination diagram show syn- collision to post-orogeny field tectonic setting (Fig. 8).


Fig. 4. (a) Total alkalis $\left(\mathrm{Na}_{2} \mathrm{O}+\mathrm{K}_{2} \mathrm{O}\right)$ versus silica $\left(\mathrm{SiO}_{2}\right)$ diagram (after Middlemost, 1994) for Paleoproterozoic granitoids of Toneta area of Lesser Garhwal Himalaya, (b) Normative feldspar classification diagrams [Albite (Ab)- Orthoclase (Or)Anorthite (An)], (after O'Connor, 1965 and Barker, 1979).
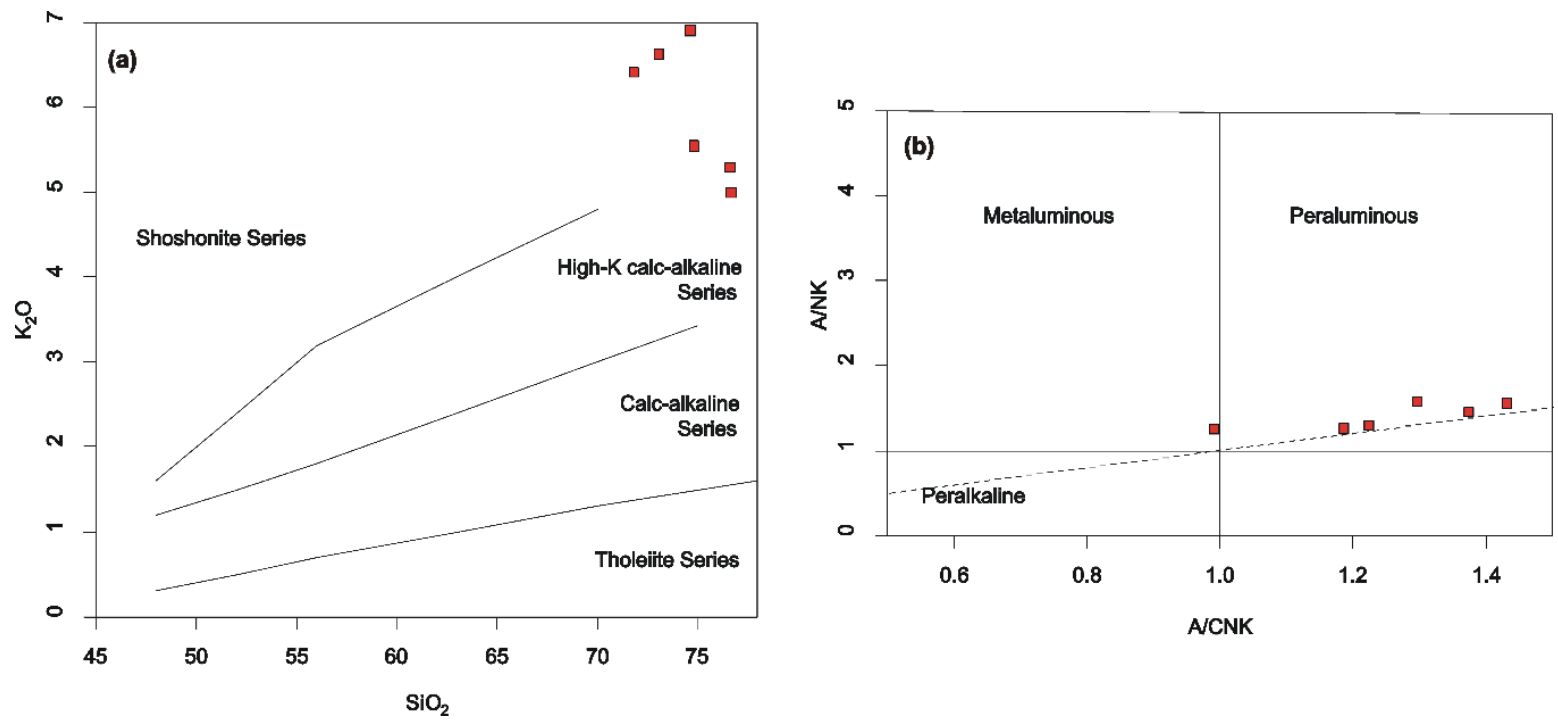

Fig. 5. (a) $\mathrm{SiO}_{2}$ vs. $\mathrm{K}_{2} \mathrm{O}$ diagram (Peccerillo and Taylor, 1976). (b) A/NK versus A/CNK diagram (after Shand, 1943).

\section{Discussion}

Phukon et al. (2018) discussed that the granitoids from the Chiplakot Crystalline Belt, Kumaun Himalaya are associated with the Columbia supercontinent subduction system in the Paleoproterozoic. Frank et al. (1977) assign a whole rock Rb-Sr age of $1840+70 \mathrm{Ma}$ for Bandal and Sainj granites, documenting an existence of Proterozoic granitic magmatism in the Himalaya. Islam et al. (2005) stated that the Proterozoic granites of the Lesser Himalaya are silica and $\mathrm{K}_{2} \mathrm{O}$ enriched with high $\mathrm{A} / \mathrm{CNK}$ value $(>1.1)$ and show presence of normative corundum. Islam et al. (2005) also pointed out that the granite, granitic gneisses and associated metasedimentaries rocks in NW Himalaya experienced up to upper amphibolites facies metamorphism which might suggest that the Proterozoic granitic gneisses were derived as basement slivers from middle crustal level (a probable extension of the northern Indian craton). Singh et al. (2009) also indicated that the Paleoproterozoic (ca. $1860 \mathrm{Ma}$ ) felsic magmatic rocks are widespread in the Lesser Himalayan Zone to basal part of the Higher 
Himalayan Crystalline (HHC) probably remobilization of older crustal material which exhumed due to collisional tectonics during the Himalayan orogeny.

The Proterozoic tourmaline-bearing granitoids rocks from NW Himalaya have typical for collisional MPG (Barbarin, 1999) petrography. They are enriched in LREE and moderately depleted HREE along with a pronounced negative Eu anomalies and characterized by negative $\mathrm{Ba}, \mathrm{Nb}, \mathrm{Sr}, \mathrm{P}$ and $\mathrm{Ti}$ anomalies and high $\mathrm{Rb}$, Th and $U$ content (Miller et al., 2000). The Sr and Nd isotopic characteristics of these rocks show their high initial ${ }^{87} \mathrm{Sr} /{ }^{86} \mathrm{Sr}$ ratios (0.711-0.721) and initial epsilon Nd values are -5.8 to -8.8 which suggest large-scale reworking of Archean sialic protolith (Miller et al., 2000). Singh (2011) suggested that 1800-2000 Ma granites from Lesser and Higher Himalaya can be correlated for tectono-thermal (collisional) event which also noticed as huge hydrothermal activity occur ca. 1.9-1.8 Ga in Bundel khand Craton (Slabunov et al., 2017), southern adjacent part of Garhwal Himalaya. It seems to be similar granitic magmatism occurs in the Lesser Garhwal Himalaya and further studies are needed to establish the remobilization of Archean crust could be of Bundelkhand or Aravalli Cratons.
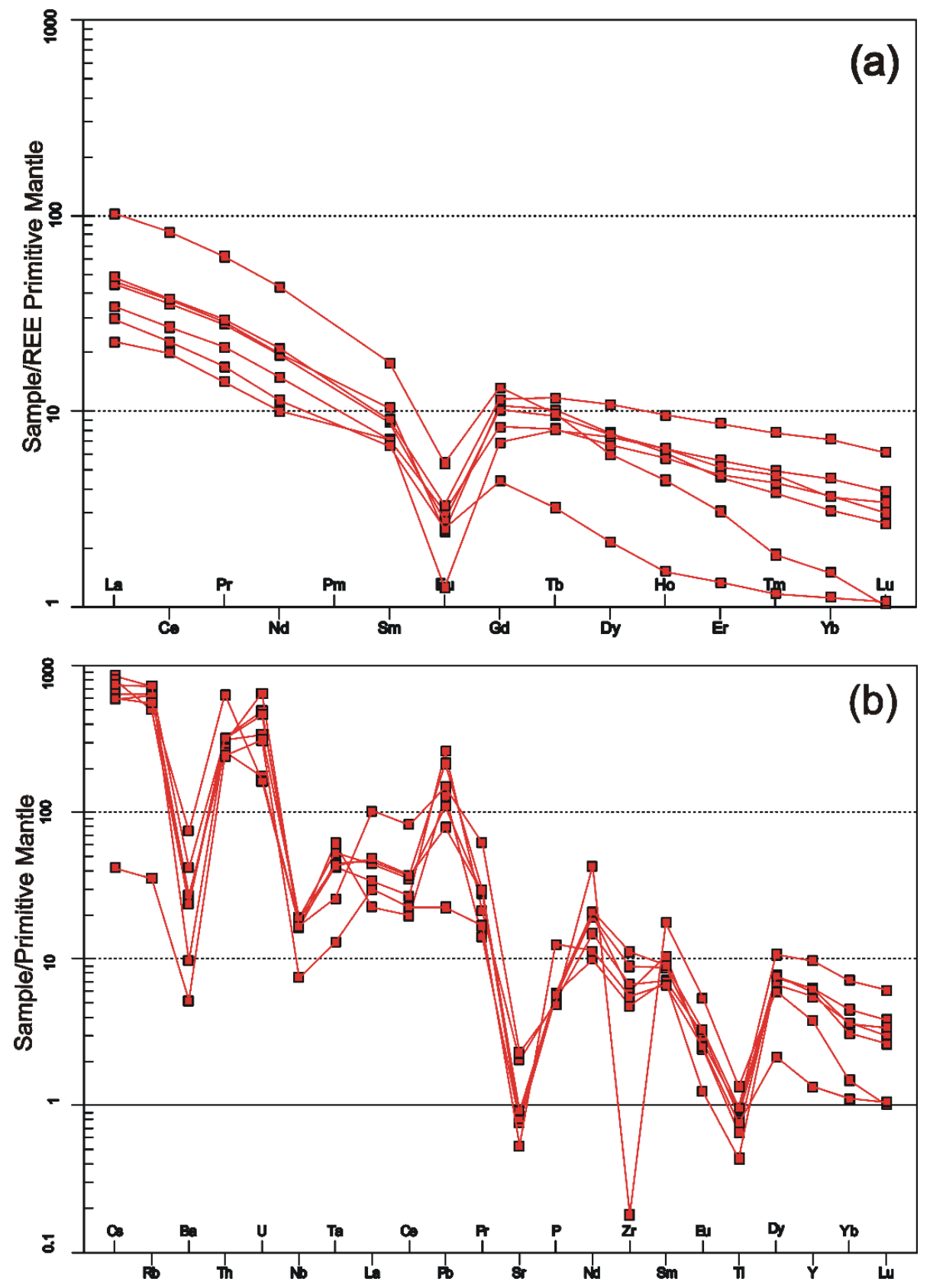

Fig. 6. (a) The chondrite normalized (after McDonough and Sun, 1995) REE plot for Toneta granites. (b) Mantle normalized multi element spider diagram of Toneta granites (after McDonough and Sun, 1995). 

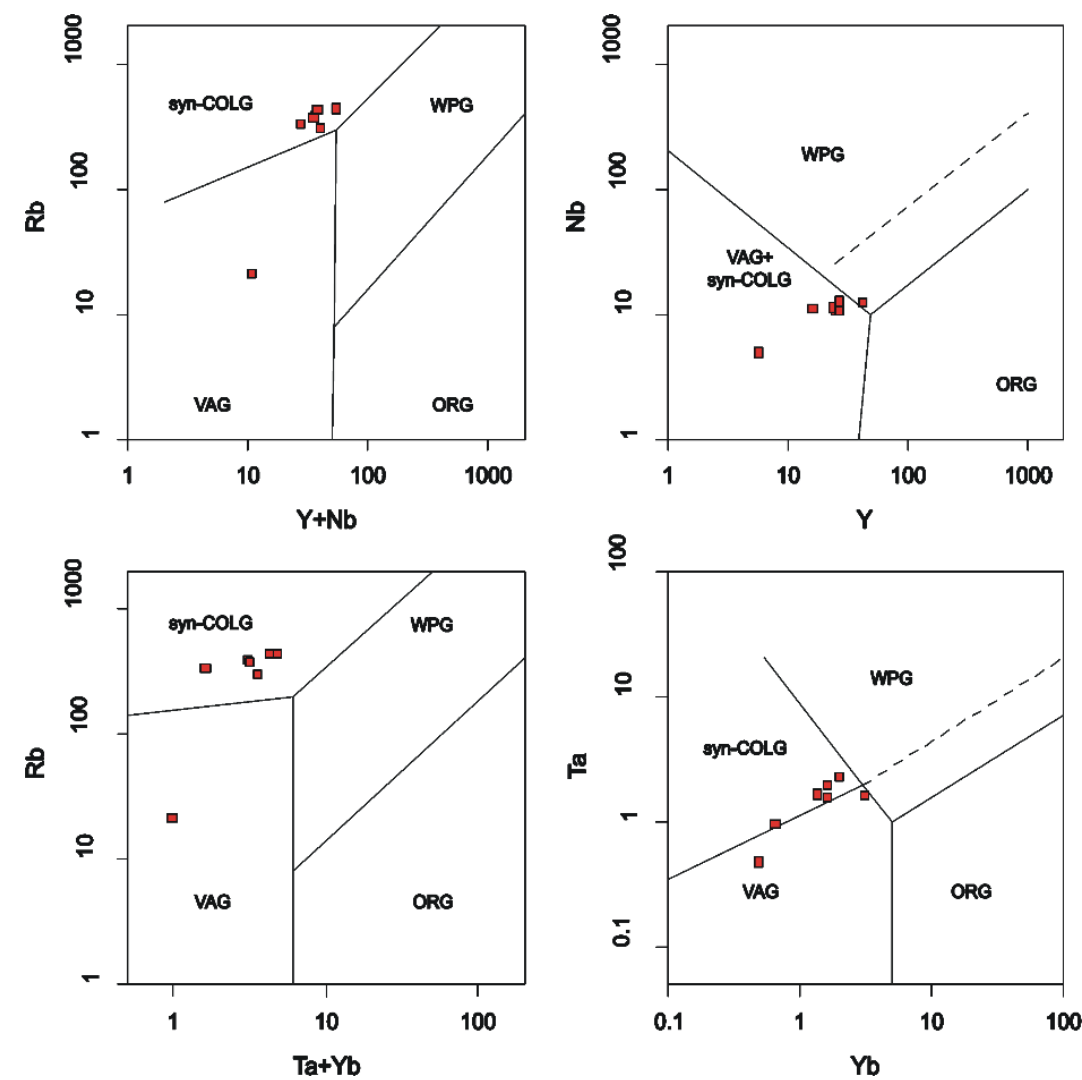

Fig. 7. Discrimination diagram of Rb-Y +Nb, Nb-Y (Pearce et al., 1984) for the Toneta granites ORG: Ocean Ridge Granites; synCOLG: Syn-Collision Granites; VAG: Volcanic Arc Granites; WPG: Within Plate Granites.

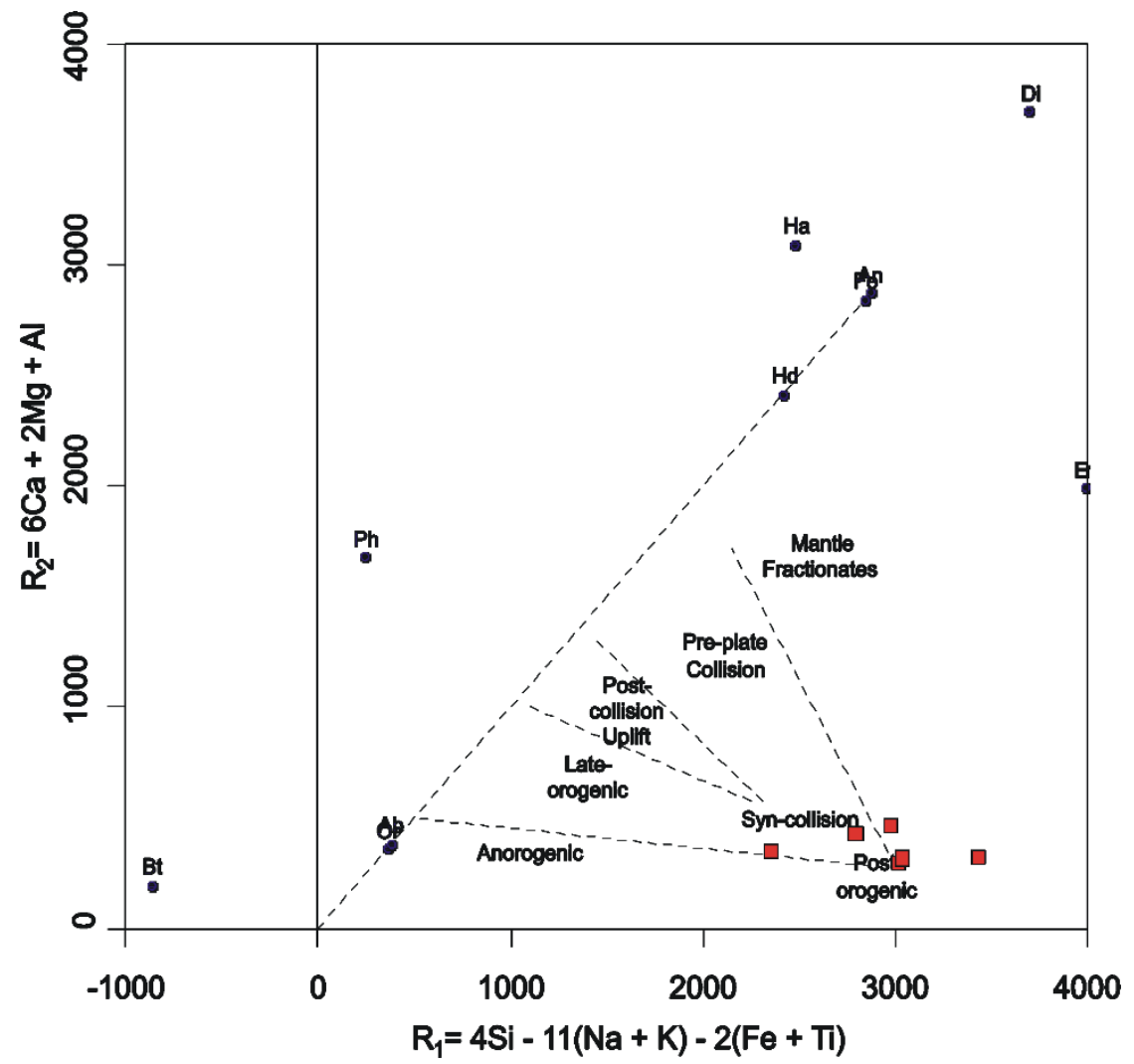

Fig. 8. R1-R2 multicationic variation diagram $\left[\mathrm{R}_{1}=4 \mathrm{Si}^{4+}-11\left(\mathrm{Na}^{+}+\mathrm{K}^{+}\right)-\left(\mathrm{Fe}^{3+}+\mathrm{Ti}^{4+}\right)\right.$, molar; $\mathrm{R}_{2}=6 \mathrm{Ca}^{2+}+2 \mathrm{Mg}^{2+}+\mathrm{Al}^{3+}$, molar $]$, (Batchelor and Bowden, 1985). 


\section{Conclusions}

To The collision tectonics nature of granites exists in Garhwal Himalaya demonstrate felsic magmatic phase implication occur during Pal eoproterozoic ages.

The Lesser Garhwal Himalaya Toneta granites formed syn-collision to post-orogeny tectonic environment, which resemble with ca. 1800-1900 Ma existing hydrothermal activity in Bundelkhand Craton suggest a possible linkage to it.

However, the questions are still unanswered and required more studies to understand about the nature of granitic rocks of Garhwal Himalaya whether these rocks have formed due to the melting and recrystallization of pre existing Archean continental crust of Bundelkhand or Aravalli Cratons?

\section{Acknowledgements}

We thanks to the Director Prof. S.S. Svetov, Institute of Geology, KarRC, RAS, Petrozavodsk, Russia for providing lab facilities for geochemical analysis. SM is thankful to DST/ INSPIRE Fellowship/ [IF160096] for financial assistance.

\section{References}

Barbarin, B., 1999. A review of the relationships between granitoid types, their origins and their geodynamic environments. Lithos 46, 605-626, doi:10.1016/S0024-4937(98)00085-1

Barker, F., 1979. Trondhjemite: definition, environment and hypotheses of origin. In: BARKER, F. (ed.) Trondhjemites, Dacites, and Related Rocks. Elsevier, Developments in Petrology, Amsterdam 6, 1-12, doi:10.1016/B978-0-444-41765-7.50006-X

Batchelor, R.A., Bowden P., 1985. Petrogenetic interpretation of granitoid rock series using multicationic parameters. Chem Geol 48, 43-55. doi: 10.1016/0009-2541(85)90034-8

Bhanot, V.B., Bhandari, A.K., Singh, V.P., Kansal, A.K., 1979. Geochronological and geological studies of granites of Higher Himalaya, Northeast of Manikaran, H.P. Journal of Geololgical Society of India 20, 90-94.

Bhanot, V.B., Kwatra, S.K., Kansal, A.K., Pandey, B. K., 1978. Rb-Sr whole rock age for Chail Series of Northwestern Himalaya. Journal of Geological Society of India 19, 224-227.

Bhanot, V. B., Singh, V. P., Kansal, A. K., Thakur, V. C., 1977. Early Proterozoic Rb-Sr whole rock age for Central Crystalline gneiss of Higher Himalaya, Kumaun. Geological Society of India, 18, 90-91.

Frank, W., Thoni, M., Purtscheller, F., 1977. Geology and petrography of Kulu-South Lahul area. Colloquium International Center for Natural Research Sciences 33, 147-172.

Fusch, G., Sinha, A.K., 1978. The tectonics of the Garhwal-Kumaun lesser Himalaya-Jb.Geol.B-A, 121 (2), 219-241, Wein.

Gansser, A., 1993. Facts and theories on the Himalayas. Jour. Geol. Soc. India 41, 487-508.

Gansser, A., 1964. Geology of the Himalayas. Wiley Inter Science, New York, 289.

Heim, A., Gansser, A., 1939. Central Himalaya, Geological observations of Swiss expedition 1936. Mem. Soc. Helv. Sci. Nat., 73, 245.

Islam, R., Ahmad, T., Khanna, P.P., 2005. An overview on the granitoids of the NW Himalaya. Himalayan Geology 26 (1), $49-60$.

Kwatra, S.K., Bhanot, V.B., Kakar, R.K., Kansal, A.K., 1986. Rb-Sr radiometric ages of the Wangtu Gneissic Complex, Kinnaur district, Higher Himachal Himalaya. Bulletin of Indian Geologists' Association 19, 127-130.

McDonough, W.F., Sun, S.-S., 1995. Composition of the Earth. Chemical Geology 120, 223-253. doi: 10.1016/00092541(94)00140-4.

Middlemost, E.A.K., 1994. Naming Materials in the Magma Igneous System. Earth-Science Review 37, 215-224, https://doi.org/10.1016/0012-8252(94)90029-9

Miller, C., Klotzli, U., Frank, W., Thoni, M., Grasemann, B., 2000. Proterozoic crustal evolution in the NW Himalaya (India) as recorded by circa $1.80 \mathrm{Ga}$ mafic and $1.84 \mathrm{Ga}$ granitic magmatism. Precambrian Research 103, 191-206.

Negi, S. S., Sinha, A. K., Pandey, B. K., 1980. "A Preliminary Report on the Geology and Structure of the Rudraprayag- TilwaraMayali Area of Garhwal Himalaya," Himalayan Geology 10, 211-219

O'Connor, J.T., 1965. A classification for quartz-rich igneous rocks based on feldspar ratios. US Geological Survey Professional Paper B 525, 79-84.

Pandey, B. K., Singh, V. P., Bhanot, V. B., Mehta, P.K., 1981. Rb-Sr geochronological studies of the gneissic rocks of the Ranikhet and Masi area of Almora Crystallines, Lesser Himalaya, Kumaun, U.P. Abstract Himalayan Geology 12th Seminar.

Paul, D. K., Mcnaughton, N. J., Chatopadya, S., Ray, K. K., 1996. Geochronology and Geochemistry of the Lingtse Gneiss, Darjeeling-Sikkim Himalaya: revisited. Journal of Geological Society of India 48, 497-506.

Patriat, P., Achache, J., 1984, India-Eurasia collision chronology has implications for crustal shortening and driving mechanisms of plates. Nature 311, 615-621.

Pearce, J. A., Harris, N.W., Tindle, A.G., 1984. Trace element discrimination diagrams for the tectonic interpretation of granitic rocks. J Petrology 25, 956-983. doi:10.1093/petrology/25.4.956

Peccerillo, A., Taylor, S.R., 1976. Geochemistry of Eocene calc-alkaline volcanic rocks from the Kastamona area, northern Turkey. Contribution to Mineralogy and Petrology 58, 63-81, https://doi.org/10.1007/BF00384745

Phukon, P., Sen, K., Srivastava, H.B., Singhal, S., Sen, A., 2018. U-Pb geochronology and geochemistry from the Kumaun Himalaya, NW India, reveal Paleoproterozoic arc magmatism related to formation of the Columbia supercontinent, Geological Society of America, https:// doi .org/10 .1130/B31866.1

Powell, C., McA., Crawford, A.R., Armstong, R.L., Prakash, R., Wynne-Edwards, H.R., 1979. Reconnaissance Rb-Sr dates for the Himalayan Central Gneiss, Northwest India. Indian Journal of Earth Sciences, 6, 139-151.

Raju, B.N.V., Chabria, T., Prasad, R.N., Mahadevan, T.M., Bhalla, N.S., 1982. Early Proterozoic Rb-Sr isochron age for Central Crystalline, Bhilangana valley, Garhwal Himalaya. Himalayan Geology, 12, 196-205.

Rao, D.R., Sharma, K.K., Gopalan, K., 1995. Granitoid rock of Wangtu Gnessic Complex, Himachal Pradesh: an example of in situ fractional crystallization and volatile action. Journal of Geological Society of India 46, 5-14.

Rao, P.S., 1998. Kameng Orogeny, 1.8-1.9 Ga. from the isotopic evidence of the Bomdila orthogneisses, Kameng Sector, NEFA, India. Geological Bulletin, University of Peshawar, 31, 159-162. 
Saklani, P.S., 1993. Geology of the Lower Himalaya (Garhwal). International Books and Periodicals Supply Service, New Delhi, 246.

Saklani, P.S., Nainwal, D.C., Singh, V.K., 1991. Geometry of the composite Main Central Thrust (MCT) in Yamuna valley, Garhwal Himalaya, India. N. Jb. Geol. Palaont. Mh., 1991, 364-380.

Shand, S.J., 1943. Eruptive Rocks. Their Genesis Composition. Classification, and Their Relation to Ore-Deposits with a Chapter on Meteorite. John Wiley \& Sons, New York.

Singh, S., Claesson, S., Jain, A.K., Sjoberg, H., Gee, D.G. Manickavasagam, R.M., Andreasson, P.G., 1994. Geochemistry of the Proterozoic peraluminous granitoids from the Higher Himalayan Crystalline, HHC and Jutogh Nappe, Himachal Pradesh, India. (Abstract volume) Journal of Geological Society of Nepal 10, 125.

Singh, S., Jain, A.K., Barley, M.E., 2009. SHRIMP U-Pb $\sim 1860$ Ma anorogenic magmatic signatures from NW Himalaya: implications for Paleoproterozoic assembly. In: Reddy, S.M., Mazumdar, R., Evans, D.A.D. \& Collins, A.S. (eds.) Paleoproterozoic Supercontinents and Global Evolution. The Geological Society London, Special Publicaltion 323, 283300. doi: $10.1144 / S P 323.14$

Singh, V.P., Bhanot, V.B., Singh, R.P., 1985. Geochronology of the granitic and gneissic rocks from Munsiari, Namik and Tawaghat areas of the Central Crystalline Zone, Kumaun Himalaya, U.P. 3rd National Symposium on Mass Spectrometry, Hyderabad, September 22-24

Singh, V.P., Singh, R.P., Bhanot, V.B., 1986. Rb-Sr isotopic studies for the granitic and gneissic rocks of Almora area of Almora Crystallines, Kumaun Himalaya, U.P. 4th National Symposium on Mass Spectrometry, Bangalore, EPS-1, 1-4.

Singh, V.K., 2011. Structural and Metamorphic evolution of the rocks of the Garhwal Himalaya: possible linkage with Bundelkhand craton, India. Proceeding of the 2nd International Conference Precambrian Continental Growth and Tectonism (Editors: V.K. Singh \& Ram Chandra), 20-35.

Singh, V.K., Slabunov, A., 2015. The Central Bundelkhand Archaean greenstone complex, Bundelkhand craton, central India: geology, composition, and geochronology of supracrustal rocks. International Geology Review 57, 1349- 1364.

Singh, V.K., Singh, S.P., Saklani, P.S., Dubey, C.S., 1998. Mesostructures and deformational history of the Central Crystallines: an example from Garhwal Himalaya, India. J. Nepal Geol. Soc., 17, 59-69.

Sinha, A.K., 1989. Geology of the Higher Central Himalaya. John Wily \& Sons, 219.

Slabunov, A.I., Singh, V.K., 2018. Meso-Neoarchaean crustal evolution of the Bundelkhand Craton, Indian Shield: new data from greenstone belts. International Geology Review, doi:10.1080/00206814.2018.1512906.

Slabunov, A.I., Singh, V.K., Shchiptsov, V.V., Lepekhina E. N., Kevlich V.I., 2017. A new Palaeoproterozoic (1.9-1.8 Ga) event in the crustal evolution of the Bundelkhand Craton, India: the results of (SHRIMP) Dating of zircons from giant quartz veins. In: Slabunov, A.l., Svetov, S.A., and Baltibaev, Sh.K. (eds.), Early Precambrian vs Modern Geodynamics. Extended Abstracts and Field Trips Guide. Petrozavodsk: KarRC RAS, 239-241.

Svetov, S.A., Stepanova, A.V., Chazhengina, S.Y., Svetova, E.N., Rybnikova, Z.P., Mikhailova, A.I., Paramonov, A.S., Utitsyna, V.L., Ekhova, M.V., Kolodey, B.S., 2015, Precision geochemical (ICP-MS, LA-ICP-MS) analysis of rock and mineral composition: the method and accuracy estimation in the case study of Early Precambrian mafic complexes. Proceedings of the Karelian Research Centre RAS. No 7. Precambrian Geology Series 54-73. doi: 10.17076/geo140

Thakur, V.C., 1992 Geology of western Himalaya, Pergamon Press Ltd., London, 355.

Trivedi, J.R., Gopalan, K., Valdiya, K.S., 1984. Rb-Sr ages of granitic rocks within the Lesser Himalayan nappes, Kumaun, India. Journal of Geological Society of India 25, 641-653.

Valdiya, K.S., 1980. Geology of the Kumaun Lesser Himalaya. Wadia Institute of Himalayan Geology, Dehradun, 291. 